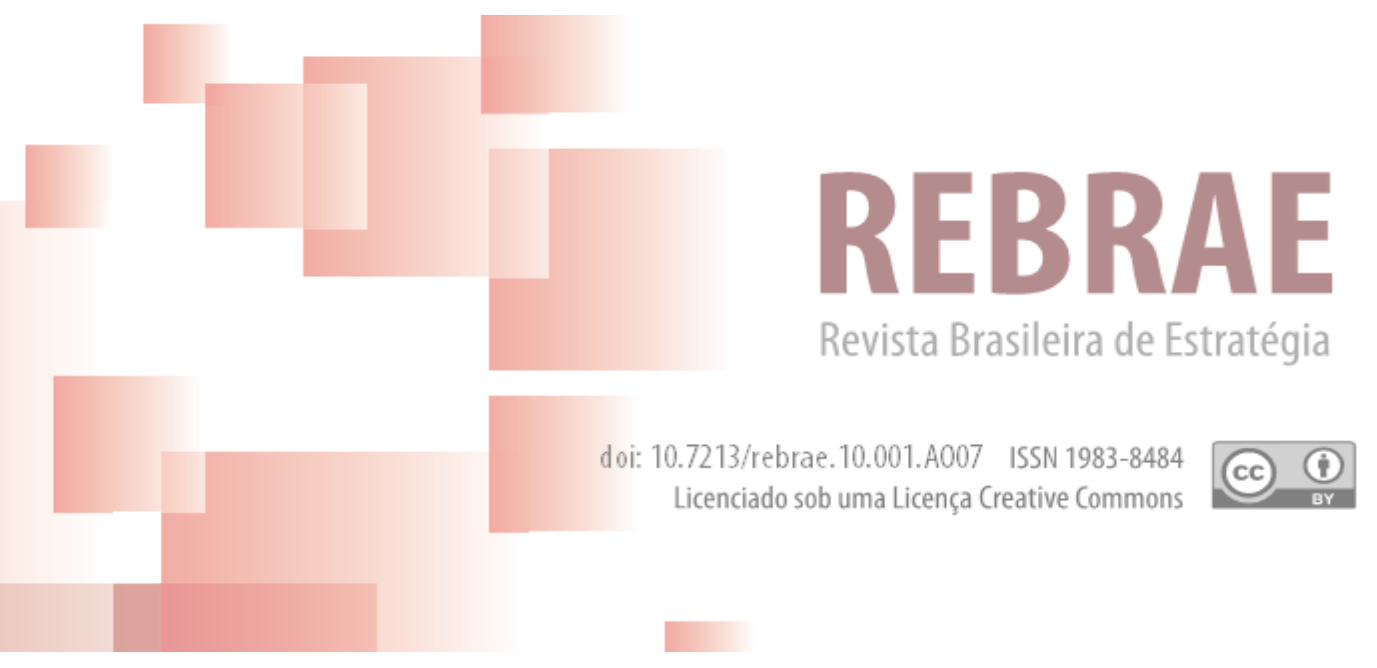

\title{
Webjet's competitive strategy from a game theory perspective
}

\author{
Jean Max Tavares ${ }^{[a]}$, Humberto Elias Garcia Lopes ${ }^{[b]}$
}

[a] Post Doctorate in Economics. Adjunct Professor - Department of Economics - PUC Minas. Belo Horizonte, MG, Brazil. E-mail: jeanpucminas@pucminas.br

[b] Doctor in Business Administration. Adjunct Professor - Programa de Pós-Graduação em Administração da PUC Minas. Belo Horizonte, MG, Brazil. E-mail: heglopes@pucminas.br

\begin{abstract}
The Brazilian commercial aviation market has undergone several changes over the past decade with the entry of GOL Airlines (1999) and the exit of firms such as TRANSBRASIL, VARIG and VASP. In 2005, WEBJET obtained a concession for regular public transport, but faced a price war with the traditional companies, coming to suspend its operations less than six months later. Regarding these events, this article aims to show how the reaction of incumbent firms was to the entry of WEBJET into the marketplace, by using Game Theory and the support of the literature on barriers to entry. Through the creation and the resolution of a Dynamic Game of Complete and Imperfect Information, it has been found that WEBJET seems to have underestimated the reaction of the incumbent firms like GOL and TAM, as well as the degree of passengers' loyalty to the incumbent firms.
\end{abstract}

Keywords: Aviation. Barriers. Game theory.

\section{Introduction}

The aviation industry has been through profound transformations with respect to mergers, modeling, acquisitions, bankruptcies, infrastructure problems, relationships with regulators, levels of concentration and competition, predatory pricing, among others. These scenarios have caught the attention of academic literature in recent years, indicated by the expressive number of published works (Sagers, 2009; Kwoka \& Shumilkina, 2010; Gedge et al., 2012; Goetz \& Shapiro, 2012; Ueda, 2012; Hu et al., 2013; Ellen \& Moreira, 2014; Park, 2014; Souza, 2014; Pereira \& Caetano, 2015, Person et al., 2015). 
Several events have justified the emergence of research involving the aviation industry in Brazil (Oliveira et al., 2006; Miotto et al., 2008; Sampaio Melo, 2008; Oliveira, 2009; Camilo Pereira, 2010; Tadeu Silva, 2011; Santos et al. 2013; Melo Filho et al., 2015; Pacheco et al., 2015), namely: a) the bankruptcy of large companies, such as TRANSBRASIL, VASP and VARIG (Helms, 2010); b) the fact that national companies can only operate in domestic markets; c) the concession system that exists "of being awarded", rather than auctioned by the Government; and finally, d) two major airlines GOL and TAM - have together over $75 \%$ of the market share - with the airline AZUL holding $16.7 \%$, in third place (ANAC, 2013).

In spite of these scenarios and the traditional barriers of aviation industrymileage programs and the location of booths (slots) in airports being sold out (Cravo, 2013) - three new companies entered the Brazilian market in 2005: BRA, TAF and WEBJET (a nationwide operation which began in February of 2005).

However, in November 2005, WEBJET temporarily suspended its flights as it could not achieve a 35\% occupancy rate. Apparently, this was due to a price war that was sparked by the traditional companies. They also used the terms of expansion strategies and different forms of payment for the value of ticket promotions. Feeling discouraged by these strategies, WEBJET enlisted the Secretariat of Economic Law (ELS) of the Ministry of Justice to prove that these strategies were deployed to artificially reduce prices, eliminating WEBJET from the market.

Based upon these facts, a question has arisen regarding a possible error of expectations on the part of WEBJET in relation to the possible reactions of the already established companies. Therefore, the problems of research for this article has been to identify what would have been the readings of the marketplace made by WEBJET, before starting its operations, both in relation to the prices charged by the companies of GOL and TAM, as well as the degree of loyalty of their customers, in a market that is characterized by asymmetric information (Church \& Ware, 2000).

Thus, the objective of this article has been to identify under what circumstances did the input and the output of WEBJET in 2005, particularly the reaction of those existing companies and the prior reading of the marketplace that were made by this company. This should have been achieved through the framework of Game Theory, which was also used by Bresnahan and Reiss $(1990,1991)$, in order to examine the effects of the entry of smaller airlines into the Brazilian capital market powers.

Theoretically, this work will help to understand the limitations of Game Theory in similar situations, because of the assumption of rationality that is required on the part of the players involved. In academic terms, this work will expand the discussions about the variability of reactions from the incumbent firms in an oligopoly, through which, under very similar scenarios, the incumbent companies react so differently. Finally, this article will break new ground by considering the strategic interdependence between the incumbent and the incoming airlines in the Brazilian marketplace from the perspective of Game Theory. This will be unlike other works that can be found in the literature (COELHO ET AL., 2007, NOBRE, 2012), which have not taken into account the possible strategies taken by competing companies. 


\section{Theoretical}

The Brazilian civil aviation market is a sector of strategic national interest which employs more than 35,000 direct and indirect employees (ANAC, 2013). Because of its importance, it has attracted the attention of researchers in recent years (Oliveira et al., 2006; Silveira \& Oliveira, 2008; Pacheco et al., 2015). A possible explanation for this is that in the decade of the 1990s, several episodes marked this industry in Brazil, both in relation to the behavior of collusions between the companies, as well as the reaction of the incumbent companies, vis-à-vis other companies (Goolsbee et al., 2008; Hu et al., 2013).

In addition, several lawsuits occurred in the early 1990s (Table 1), signaling a difficult scenario for any incoming company.

Table 1- Major Antitrust Investigations carried out in Brazilian Air Transport

\begin{tabular}{|c|c|c|c|}
\hline Date & $\begin{array}{l}\text { Type } \\
\text { of Process }\end{array}$ & Object & $\begin{array}{l}\text { Companies } \\
\text { Involved }\end{array}$ \\
\hline March/2000 & Conduct & $\begin{array}{l}\text { Coordinated and Uniform Reduction of Commission to Travel } \\
\text { Agencies }\end{array}$ & $\begin{array}{l}\text { VARIG, TAM, VASP } \\
\text { and } \\
\text { TRANSBRASIL } \\
\end{array}$ \\
\hline April/2000 & Conduct & $\begin{array}{l}\text { Imbalance of Competition in the Industry that was alleged by } \\
\text { TAM due to the Defaults of VASP }\end{array}$ & VASP \\
\hline May/2000 & $\begin{array}{l}\text { Structure and } \\
\text { Conduct }\end{array}$ & $\begin{array}{l}\text { Operating Agreements, followed by a Reduction of Seating } \\
\text { and an Increase in Prices }\end{array}$ & $\begin{array}{l}\text { TAM and } \\
\text { TRANSBRASIL }\end{array}$ \\
\hline May/2000 & $\begin{array}{l}\text { Structure and } \\
\text { Conduct }\end{array}$ & Aircraft Sales and Transfer Lines & VARIG and VASP \\
\hline February/2001 & $\begin{array}{l}\text { Structure and } \\
\text { Conduct }\end{array}$ & $\begin{array}{c}\text { Reports of Restrictions on Entry; Combination of } \\
\text { Discounts in the Month in which GOL started Operations; } \\
\text { nion Workers in Companies lobbying DAC to Prevent the } \\
\text { Acceptance of New Companies }\end{array}$ & VARIG and TAM \\
\hline
\end{tabular}

Source: Adapted from Turolla, F. A., Lovadine, D., Oliveira, A. V. M. (2006). Competition, Collusion and Antitrust: Estimation of the Competitive Conduct of Airlines. Rev. Bras. ECON. [online]. 60 (4), 425-459.

\section{Oligopoly and Barriers to Entry}

According to Sanchez (2008), the commercial aviation industry in Brazil has been characterized by an oligopoly with differentiated products (services). Valent et al., (2014, p. 126) mentioned that "in the last two decades, thanks to the uncertainties and the constant fluctuations, the respective economic scenarios have changed and have, thus, becoming an oligopoly".

One of the main features of an oligopolistic industry is a barrier to the entry of new firms. Among them, we have highlighted price fixing, that as a strategy of maximizing long-term earnings (authors), would allow an incoming company to only recover its costs, plus a profit rate that would be considered to be normal, in which case, the prospective entry's entrance would not occur.

With regard to prices, the incumbent companies can practice predatory pricing. This would be defined, when practiced, as "when one firm reduces the sale price of its products below cost, incurring losses in the short term, in order to 
eliminate rivals or potential market entrants, and then to later, when the rivals are out of the marketplace, to raise prices once more" (SEAE, 2002, p. 2).

In this case, the incumbent company (the predator and, usually, a market leader) suffers losses (negative profits) during the time in which it becomes the company's strategy. After this period, the rivals end up out of the marketplace and the predator can elevate its investments, increase its prices to the level of a monopoly and then benefit from positive profits (Dawid et al., 2013). In this sense, the main anti-competitive conduct in the air sector would enhance "an excessive capacity, predatory pricing (versus promotional prices), illicit cooperation agreements and cartels, grant preferential commissions to travel agents and endorse the misuse of computerized reservation systems" (FERREIRA, 2007, p. 47).

For these anti-competitive practices to be effective, they must occur for a determined period of time and in a concentrated market, as well as having significant entry barriers, so that the entrants do not return quickly to the marketplace (Robenalt, 2007). In addition to these practices, these companies may set a threshold price in order to discourage entrants by setting a lower price. The entrants may then be induced to believe that the post-entry prices could even be lower and then decide not to enter. These price limits would be the highest prices that the firms could charge without attracting new entrants into the marketplace.

The determination of lower prices than those charged in monopolies by oligopolists was initially investigated by Bain (1956), who concluded that this approach could be justified in order to prevent the attraction of new companies (potential competition) and even to a price war in the future. Meghan (2002, p. 299) found that a price war "is a period in which one firm in an industry or in a market establishes a price far below the price that is usually practiced. This occurs because a firm, noting the prices of its competitors, has a difficulty in interpreting them as a cause for the fall in demand for its products, or as a sign that one of its competitors has offered a lower price to their customers".

Other traditional barriers to entry in oligopolistic industries are the advantages of absolute costs, consumer preferences, and the economies of scale (Franco et al., 2002).

In relation to absolute cost advantages, these manifest themselves when the incoming company stumbles upon average costs that are greater than those that were observed before its entrance into the marketplace. These advantages originate from technological expertise, privileged conditions of access to productive factors, an easier access to investment funds, and the training of qualified human resources, among others.

As to the preferences of consumers, these can focus on a product or a service to the detriment of the one offered by a new bidder, forcing him to practice at a lower price, or to afford and engage in higher advertising spending, changing the way the cost-price ratio is unfavorable for the incoming company.

There are numerous reasons that may set the preferences for a particular brand, such as a reputation developed over some time, distribution networks and broader assistance, a longer work of disclosure that may have already occurred, consumer loyalty, as well as additional services that add value to a shopping experience. 
In the aviation industry, a possible preference for users, to the detriment of new starters, would be the fact that they can understand that large and modern aircraft are more secure and more comfortable than others, which would require having aircraft at a higher level of service than its competitors, especially on busier routes.

Upon the market entry of GOL Airlines in 2001, these preferences seemed to mean, in practice, the loyalty of users to an air transport system, in a market that had been presented for a long time with the same companies - VARIG, VASP and TRANSBRASIL - with an emphasis on the first. From then on, with another large company's option and with new aircraft, the fidelity of these users was becoming to apparently dwindle, with a high sensitivity to prices.

Recently, Santos et al., (2013) calculated the price elasticity of demand in the air sector of Brazil, getting a result of 1.93. Soon, this demand, being elastic, can affect the loyalty of users. This was explained in a document from AZUL Airlines, which stated that this particular sector was highly sensitive to discount rates and aggressive pricing policies (AZUL, 2013).

The economies of scale may be real (derived from a cost reduction, as an example) or in cash (arising from the payment of lower prices for the acquisition of inputs, transport services, advertising, the interest costs of aircraft leasing, among others). Therefore, a company interested in the civil aviation marketplace in Brazil must meet with the incumbents, as it pertains to weight advantages and pre-existing costs, especially if the competition works via the same routes and with the prices charged by these companies (Salgado \& Guimarães, 2003). Associating the costs of asymmetrical information (Church \& Ware, 2000), it can be said that "the existence of an asymmetry of information (...) and transaction costs (...) means that the groups with a lower cost of organization are able to impose considerable costs on societies, with higher costs of organization, even if the result is inefficient" (Nobre, 2013, p. 29).

Finally, the expected profitability also depends on the reactions of the incoming companies that are being established. Regarding this, Fagundes and Pondé (2005, p. 14) claimed that "it may be advantageous to the firm to establish a dominant size (...) and production capacity, in order to influence the decisions of any incoming company, basically by just alleviating the intensity of the competition's potential". For Domingos (2005, p. 19), "only convincing threats of retaliation by the competitors already installed in a market may be able to prevent the entrance of a new company".

The practices that are adopted in the Brazilian civil aviation market seem to confirm the authors' statements above, because in Brazil, in particular, overcapacity is a strategy used by airlines to prevent the entry of or to prevent the strengthening of competitors (SEAE, 2004).

\section{Incumbent Companies versus WEBJET: A Retrospective View}

In 2005, there were 18 scheduled air transport companies in Brazil. TAM was leading the commercial aviation market in Brazil, with a $43.25 \%$ share, followed by GOL with $27.07 \%$, and by VARIG with $26.48 \%$. The other airlines amounted to a $3.20 \%$ 
market share (DAC, 2005). Only these three companies operated in 2004 as an efficient frontier (Sampaio \& Melo, 2008).

WEBJET started flying in March 2005, by entering the market with a low-cost concept, the same as GOL Airlines. This particular company was born with the intention of operating on the basis of Low Costs and Low Fares. However, it would operate with a more aggressive strategy (...), in order to operate only with its own sales (...) without the resources of travel agents, in addition to giving up a yield management resource to its segment" (Jesus Júnior, 2012, p.5).

WEBJET's entry into the operation detonated a new tariff dispute in the air market. VARIG, which had announced its last discounts of up to $80 \%$ on five routes, expanded the number of targets hit by the discounted prices. GOL, at the same time, lowered its prices in the sections operated by WEBJET. TAM announced a promotion on its airlifts (Folha de São Paulo, 2005).

After the start of operations by WEBJET, GOL announced that it would offer cheaper rates than WEBJET in some stretches, such as Brasilia-Brasilia-Guarulhos and Rio. Officially, GOL did not admit that the price changes were motivated by the entrance of WEBJET into the marketplace, but due to the market's reality. At the same time, TAM announced a promotion on the air bridge of São Paulo-Rio de Janeiro for all times and days of the week, right after the entrance of WEBJET. This kind of behavior by the incumbent firms would be expected because, according to Nobre (2012, p. 18), "companies (GOL/TAM) act aggressively in the marketplace, with a high frequency of flights on each route, allowing the customer to decide which to go on". In addition, there are works "showing how, in the presence of imperfect information, a firm that is installed can build a reputation for "playing rough" (toughness) and discourage potential entrants from running with it" (Ferreira, 2007, p. 51).

The average rate of occupation on WEBJET, even with the counterattacks of the other companies, was $59 \%$, while the industry average was $78 \%$. The point is, GOL, TAM and VARIG, had occupancy rates even higher: $80 \%, 79 \%$ and $77 \%$, respectively (Folha de São Paulo, 2005).

These performances led WEBJET's President to state that this trend would result in even greater increases of this percentage, since people are more familiar with WEBJET's philosophy, which is simple and inexpensive flying (Aviation Brazil, 2005). But this optimism did not last long. A little more than two months after that statement, the President of the company said there would be a postponement of their expansion plans, due to the tariff wars between the airlines.

In the last week of October, WEBJET had no flights for two days in a row, because of a lack of passengers (low occupancy rate). In December 2005, the company stopped flying, requesting a suspension of their flight permit to the Department of Civil Aviation. In early January 2006, WEBJET was sold to a group of businessmen from the sector of transport, tourism and foreign investor's funding.

All of these reactions were by large companies to entrants and the VARIG crisis postponed the entry of new companies into the Brazilian market, as claimed by 0 Tempo (2006). They stated that the delays may have been linked to the performances of rookies, such as WEBJET, which began flying in July and which in December, it asked to temporarily suspend its operations, due to a lack of demand. Thus, the DAC would fear that other companies would face the same difficulties (...). This fact and the VARIG 
crisis may have made the DAC to become more judicious in allowing a company to operate on scheduled air transport routes.

Oliveira (2009) pointed out some ways that can help to explain the rapid disappearance of WEBJET, namely:

a) WEBJET used a flat rate (not per thread) and with an emphasis on direct sales via the Internet without the use of travel agents, as is usual in the marketplace.

b) WEBJET started with just one aircraft and began operating in July, at the end of the high season, in addition to having entered the market along with the company BRA.

c) While at the entrance of GOL Airlines, the big companies had financial difficulties. WEBJET found more robust competition in this sense (GOL and TAM).

d) WEBJET failed to operate at Congonhas (SP), Santos Dumont (RJ) and Pampulha (MG) airports, but only operated at Guarulhos airport (SP).

However, with the strong price reaction WEBJET suffered at its entrance, it promptly retreated from its operations, it hurt its image among users of air transport and it charged the incumbent companies of a possible practice of predatory pricing (Oliveira, 2009). The situations of WEBJET and GOL Airlines may have influenced the strategy that was used by AZUL Airlines, which entered the market at the end of 2008. This was because it adopted the practice of non-predatory prices that were aligned with the market (...) consistent with a lower aggressive behavior and being a responsible challenge in a marketplace that was characterized by a near-duopoly that was formed by GOL and TAM (Oliveira, 2009, p. 20).

Therefore, the strategical interdependence in the Brazilian commercial aviation sector will enable analyzes of this specific situation through the framework of Game Theory, which will be briefly discussed below.

\section{Game Theory}

Game Theory is used in scenarios of strategical interdependence. This means that it is particularly useful when the result of a Player depends on both your actions and the actions taken by other agents, in a possible conflict of interest.

This utility makes Game Theory relevant, in order to analyze competitive strategies in several sectors, including commercial aviation (Silveira \& Oliveira, 2008; Seng Poh \& Mohd, 2011). This sector is characterized by the frequent entry and exit of enterprises (Berry, 1992; Toivanen \& Waterson, 2000; Aguirregabiria \& Chun-Yu, 2010) and by a high market concentration. For this reason, actions taken by a company can have considerable effects on their rivals (Sena, 2008; Pinto, 2008). Thus, commercial aviation has been a market structure that has been characterized by the interdependence between competitors. Consequently, the results arising from the strategies adopted by a parent company, called payoffs - may affect the strategies of competitors. Game Theory lends itself to precisely analyze these kinds of situation.

Beyond interdependence, another assumption of Game Theory is the rationality of the Players. This means that each of them will do what is best for them, regardless of the consequences. That assumption has been shown to be believable, because Players act with more rationality than one imagined a few years ago (Pinto, 2008). 
The interdependence between companies and the rationality of Players are necessary presuppositions, but they are insufficient to analyze strategies via Game Theory. This is because analyzes depend on the type of modeling, i.e., the way in which the relationships of interdependence among firms are considered. In Game Theory, this modeling considers three aspects, namely: 1) the game is dynamic or static; 2) he or she has complete or incomplete information; and 3) the game has perfect information or imperfect information.

With regard to the first aspect, the game will be static when the Players do not meet the choices of the others at a time when they take their own decisions. On the other hand, in a dynamic Game, the plays are sequential, i.e., a player takes a decision after another has done the same. As to the second point, the game will have full information when all of the Players know the payoffs of each other. Consequently, the information is incomplete when this condition is not present.

Finally, for the third aspect, the game will have perfect information when the Players always meet the strategies that are adopted by the others. Logically, the game will be imperfect, if there is asymmetrical information that prevents a broad and unrestricted knowledge of these strategies by all of the participants. These considerations are relevant in order to understand how this study has been conducted.

\section{Methodology}

In this work, we have dedicated ourselves to analyze WEBJET's strategy through the perspective of Game Theory. As described in the previous section, this analysis depends on two assumptions: 1) the interdependence among the participants, and 2) their rationality. Both of these points were met, once the civil aviation sector was highly concentrated and having assumed that all of the industry participants were rational. In other words, doing what was best for themselves - no matter what happened to the others.

This position was left to model the game, which was defined as follows: 1) it was dynamic, since the actions occurred sequentially; 2) it was complete, since the information on the aviation market's payoffs of the participants were known; and 3) it was imperfect information, because the strategies of the participants were not always known to all.

The game in this treaty work encompasses WEBJET's strategy in 2005. It was formed by two participants, who were the company GVT (formed by GOL, VARIG and TAM) and WEBJET. Figure 1 illustrates the general model of the game. 


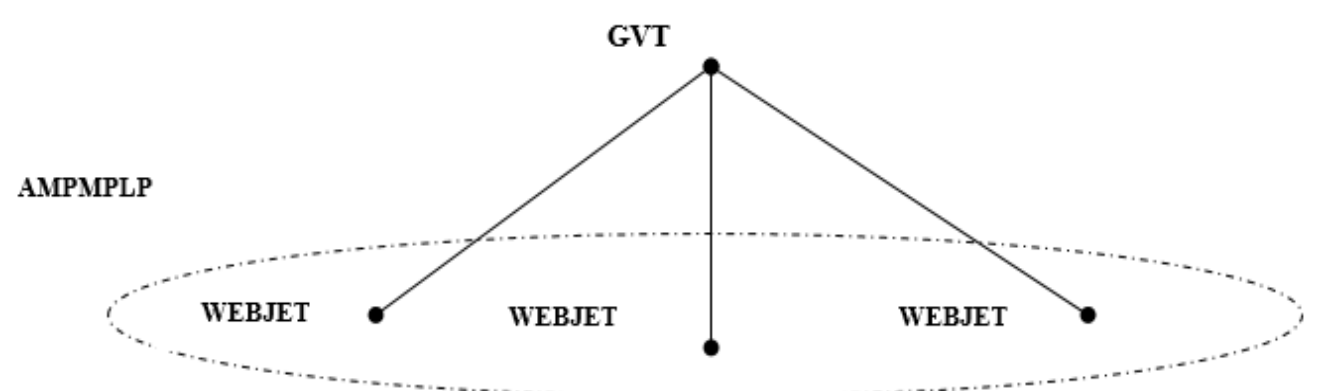

Figure 1 - Game of Complete and Imperfect Information - Part I

Source: authors

GVT is being used in this research because TAM, GOL and VARIG retaliated against WEBJET in a similar manner. In addition, these three companies had more than 90 percent of the aviation market in 2005, indicating that its strategies affected the entire sector.

In the first part of the game, the actions available to the company were: 1) an adoption of a price above the market price (map); 2) the market price (MP); or 3) a price-limit (LP).

In the modeling of the game, it was considered that there was an uncertainty about the costs of GVT. This meant that WEBJET could not have had a prior knowledge of the strategies of GVT, incurring imperfect information. In this situation, WEBJET had to decide if it should embrace the market price (MP), operate at less than the market price (LMP), or have a price-limit (LP). This choice would only be adopted if WEBJET believed that GVT practiced a sluicegate or turned out (STO) in the marketplace. Figure 2 illustrates this situation.

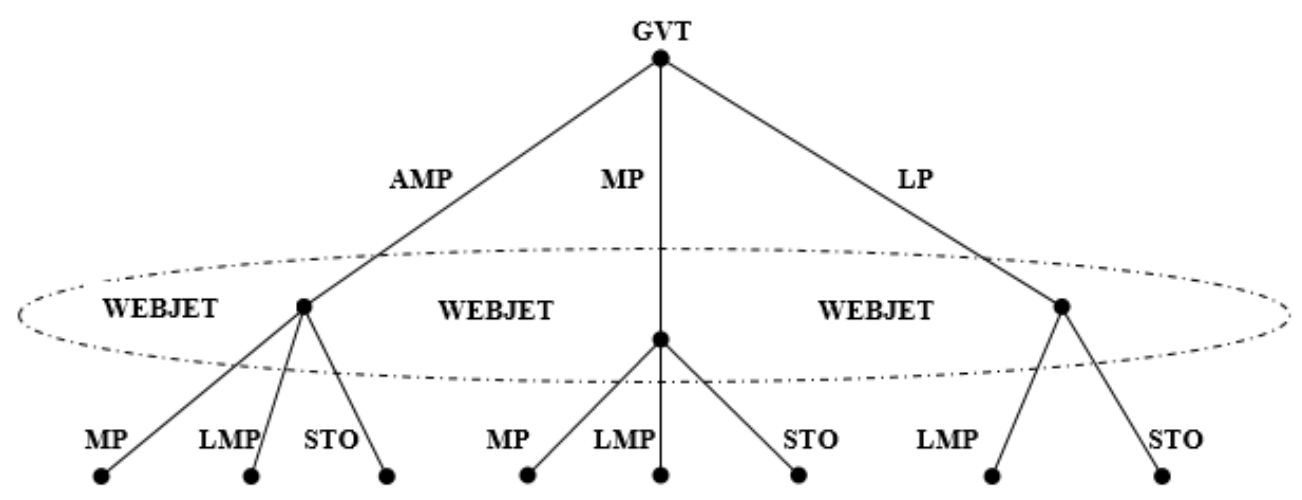

Figure 2 - Game of Strategy between WEBJET and GVT.

Source: authors.

GVT could respond to each of these actions from WEBJET in four ways: by adopting the market price (MP); operating at less than the market price (LMP); imposing a price-limit (LP); or engaging in predatory pricing (PP). Another important 
aspect in modeling the game is the relationship between the costs and the profits of the participants. In this work, the following was the notation:

$\pi^{M}=$ Profits for the commercial aviation market in Brazil

$\pi^{W X}=$ Profits of WEBJET, where $X$ represents 6 profit levels in an ascending order, such that $X=1,2,3,4,5$ and 6

$\gamma^{M A}=$ Very high sunk costs

$\gamma^{A}=$ High sunk costs

$\gamma^{M}=$ Average sunk costs

$\gamma^{B}=$ Low sunk costs

Sunk costs $(\gamma)$ in the aviation sector are those for: information on demand; to meet technical requirements and registration; for the advertising of a new company; to enter into contracts; and the relationships with the various local actors, among others (Turolla et al., 2011, p.200). The expectations of WEBJET in relation to the prices of GVT, the greater will be the stranded costs.

The payoffs are corporate profits and they follow a rule of valuation set by five hypotheses, namely:

I) Analysis is short-term. Therefore, the possible effects on the competitor and over his own company's profit in the long run are disregarded;

II) GVT's profit is greater when using AMP strategies and MP, in a descending order, regardless of what WEBJET set as their strategy;

III) GVT's greater profits in the short term are in response to an input from WEBJET regarding price maintenance;

IV) WEBJET has sunk costs when GVT opts for LMP or PP; i.e. it is forced to exit the marketplace. This is reflected by the fact that when the information about costs and demand conditions are not symmetrical, a predator can use a lower price in order to signal to a rival that with those costs and demand conditions, the best option for the rival is to stay in the marketplace and continue to face a dominant firm (Ferreira, 2007).

V) The degree of fidelity to GVT in 2005 was significant.

The payoffs are the firm's profits and they follow the rule of valuation set by five hypotheses, namely:

I) Analysis is short-term. Therefore, the possible effects on the competitor and over his own company's profit in the long run are disregarded;

II) GVT's profit is greater when using AMP strategies and MP, in a descending order, regardless of what WEBJET set as their strategy;

III) GVT's greater profits in the short term are in response to an input from WEBJET regarding price maintenance;

IV) WEBJET has sunk costs when GVT opts for LMP or PP; i.e. it is forced to exit the marketplace. This is reflected by the fact that when the information about costs and demand conditions are not symmetrical, a predator can use a lower price in order to signal to a rival that with those costs and demand conditions, the best option for the 
rival is to stay in the marketplace and continue to face a dominant firm (Ferreira, 2007).

V) The degree of fidelity to GVT in 2005 was significant.

The payoffs available after GVT chooses AMP and when WEBJET chooses to play the strategies of MP or LMP are:
$(1)=\left(\pi^{G V T 1} ; \pi^{W 1}\right)$
$(2)=\left(\pi^{G V T 2} ; \gamma^{M}\right)$
(3) $=\left(\pi^{G V T 3} ; \gamma^{A}\right)$
$(4)=\left(\pi^{G V T 4} ; \pi^{W 2}\right)$
$(5)=\left(\pi^{G V T 5} ; \gamma^{B}\right)$
$(6)=($ GVT 6 ; $M A)$

GVT payoffs have the following rules of valuation:
(A) $\pi^{G V T 1}>\pi^{G V T 2}>\pi^{G V T 3}$, based on the hypotheses of II and III
(B) $\pi^{G V T 4}>\pi^{G V T 5}>\pi^{G V T 6}$, based on the hypotheses of II and III
(C) $\pi^{G V T 1}>\pi^{G V T 4}$

WEBJET payoffs have the following rules of valuation:

(D) $\pi^{W 1}>\gamma^{M}>\gamma^{A}$, from the hypotheses of I and III

(E) $\pi^{W 3}>\gamma^{B}>\gamma^{M A}$, from the hypotheses of I, III and IV

(F) $\pi^{W 1}>\pi^{W 3}$

The payoffs available when GVT chooses MP and WEBJET responds with the strategies of MP or LMP are defined below:
$(7)=\left(\pi^{G V T 7} ; \pi^{W 4}\right)$
$(8)=\left(\pi^{G V T 8} ; \gamma^{B}\right)$
(9) $=\left(\pi^{G V T 9} ; \gamma^{M A}\right)$
$(10)=\left(\pi^{G V T 10} ; \pi^{W 5}\right)$
$(11)=\left(\pi^{G V T 11} ; \gamma^{M}\right)$
$(12)=\left(\pi^{G V T 12} ; \gamma^{M A}\right)$

GVT payoffs have the following rules of valuation:

(G) $\pi^{G V T 7}>\pi^{G V T 8}>\pi^{G V T 9}$, from the assumptions of I and III

(H) $\pi^{G V T 10}>\pi^{G V T 11}>\pi^{G V T 12}$, according to the hypotheses of I, III and IV

(I) $\pi^{G V T 7}>\pi^{G V T 10}$

Although WEBJET has not chosen how to directly choose the payoffs that are available - these have the following rules of valuation:

(J) $\pi^{W 4}>\gamma^{B}>\gamma^{M}$, from the hypotheses of I and III

(L) $\pi^{W 5}>\pi^{M}>\gamma^{M A}$, from the hypotheses of I, III and IV 
(M) $\pi^{W 4}>\pi^{W 5}$

The payoffs that are available after GVT chooses a price-limit (LP) and WEBJET chooses LMP or STO, are defined below:

$$
\begin{aligned}
& (13)=\left(\pi^{G V T 13} ; \pi^{W 6}\right) \\
& (14)=\left(\pi^{G V T 14} ; \gamma^{B}\right)
\end{aligned}
$$

The valuation rules are defined as:

(N) $\pi^{G V T 13}>\pi^{G V T 14}$, based on hypothesis I

(O) $\pi^{W 6}>\gamma^{B}$, based on hypothesis I

Once presented, the valuation rules of the payoffs and the structure of the game will be resolved as follows (Figure 3): 


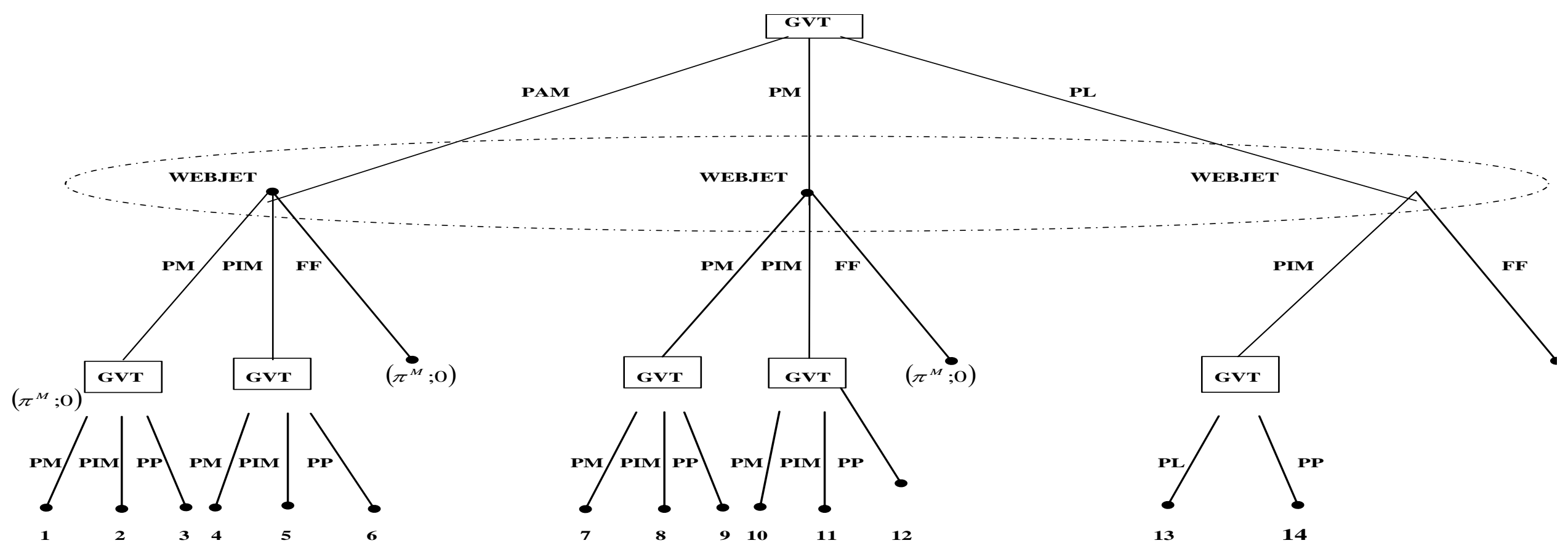

Figure 3 - Dynamic Game of Complete Information and Imperfect Information.

Source: authors 


\section{Analyzes and Discussion of the Results}

By solving a perfect piece of information by backwards induction, where the valuation rules that have been adopted for this work, the game now comes down to only a portion containing imperfect information (Figure 4).

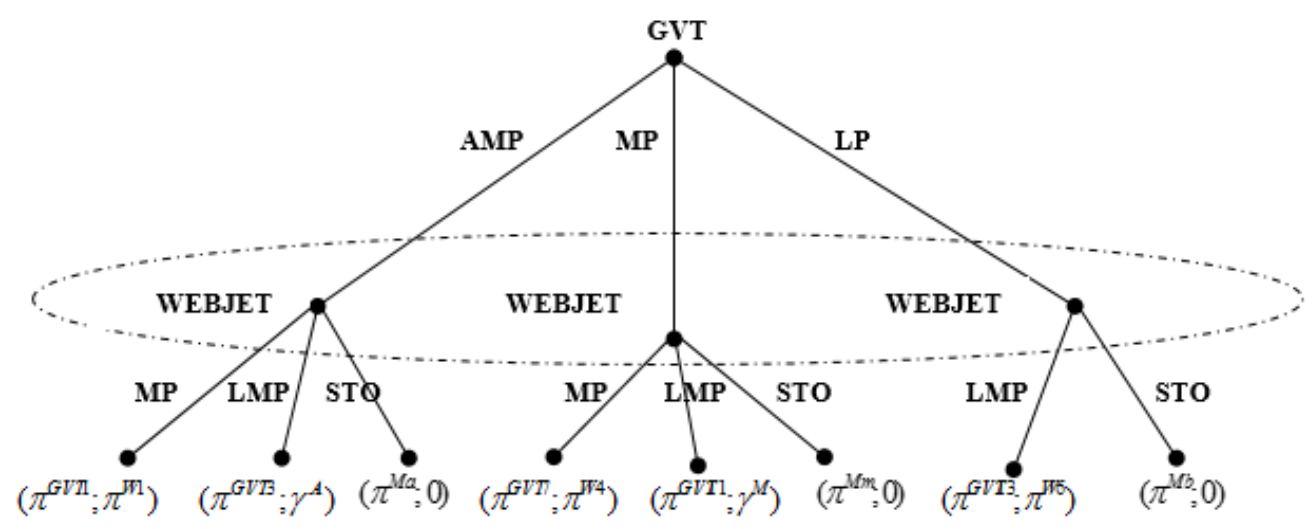

Figure 4 - Structure of the game after the resolution of the part with imperfect information.

Source: authors.

Then the game is represented in a Normal Form or a Strategic Form (Figure 5), namely:

\section{WEBJET}

\begin{tabular}{|c|c|c|c|c|}
\hline & & MP & LMP & STO \\
\hline \multirow{3}{*}{ GVT } & AMP & $\pi^{G V T 1} ; \pi^{W 1}$ & $\pi^{G V T 7} ; \pi^{W 4}$ & $\pi^{M a} ; 0$ \\
\hline & MP & $\pi^{G V T 4} ; \pi^{W 2}$ & $\pi^{G V T 10} ; \pi^{W 5}$ & $\pi^{M a} ; 0$ \\
\hline & LP & $\pi^{M} ; \gamma^{M A}$ & $\pi^{M} ; \gamma^{M A}$ & $\pi^{M} ; 0$ \\
\hline
\end{tabular}

Figure 5 - Normal Form or Strategic Form.

Source: authors.

The resolution of this game is made by an inspection of the cells by each cell, namely:

- If GVT plays AMP, the best strategy for WEBJET is to play MP;

- If GVT plays MP, the best strategy for WEBJET is to play MP;

- If GVT plays LP, the best strategy for WEBJET is to play STO;

- If WEBJET plays MP, the best strategy for GVT is to play LP;

- If WEBJET plays LMP, the best strategy for GVT is to play LP;

- If WEBJET plays STO, the best strategy for GVT is to play LP; 


\section{WEBJET}

\begin{tabular}{|c|c|c|c|c|}
\hline & & MP & LMP & STO \\
\hline \multirow{3}{*}{ TGV } & AMP & $\pi^{G V T 1} ; \pi^{W 1}$ & $\pi^{G V T 7} ; \pi^{W / 4}$ & $\pi^{M a} ; 0$ \\
\hline & MP & $\pi^{G V T 4} ; \pi^{W 2}$ & $\pi^{G V T 10}: \pi^{W 5}$ & $\pi^{M a} ; 0$ \\
\hline & LP & $\pi^{M} \gamma^{M A}$ & $\pi^{M}: \gamma^{M A}$ & $\pi^{M} 0$ \\
\hline
\end{tabular}

Figure 6 - Final Resolution of the Game.

Source: authors.

The final result of the game i.e., if WEBJET had understood that GVT was practicing LP, WEBJET should choose STO (Figure 6). Therefore, the best scenario for WEBJET would be to stay out of the commercial aviation marketplace, as a result of the incumbent company's pricing - TAM, GOL and VARIG.

However, when WEBJET was reading the game, it did not seem to have seen that GVT would be practicing, by then, a cost above the market price (map) - and that it would accommodate after its entry, to maintain the same level of prices. This belief of WEBJET may have been based on two aspects:

I) WEBJET may have underestimated the reactions of GVT, believing that its small initial volume of operations would not justify a price war.

II) WEBJET believed that the degree of loyalty of the users of air transport was low and of those migrating to it.

With that, WEBJET may have bet that all of them would split the market in the short term, so that the degree of fidelity could assist in the definition of the amount of profit to be received by each of them. However, the responses of GVT were too aggressive, to the point of suspending WEBJET's activities, even in the year of the beginnings of its operations. These results have indicated that "companies compete symmetrically with each other, but input theories show that the incumbent companies can accommodate, in relation to some incoming and outgoing use, predatory tactics with the other" (Ciliberto, 2005, p. 1).

\section{Conclusion}

The 1990s were marked in Brazilian commercial aviation by the entries and the exits of businesses. WEBJET, which began operations with a single aircraft in July 2005, had routes that competed directly with the companies of TAM, GOL and VARIG. WEBJET requested the suspension of its activities, as early as 2005 .

This work has conducted a study by the means of Game Theory, with the circumstances of the entering and the exiting of WEBJET in 2005, together with the possibility of the reactions of the incumbent companies having contributed to the suspension of WEBJET's operations less than six months later.

The results obtained in this work have shown that WEBJET should have stayed out of the Brazilian aviation marketplace, if it had attended to the assumption of limited rationality that is inherent in Game Theory. 
However, in principle, WEBJET held that GVT would not care about its entry into the marketplace, maybe because of it being so small - and believing that GVT would not have reacted with war, sacrificing part of their profits.

Maybe VARIG and TAM learned their lessons from the occasion of GOL Airlines, which was also considered too small, but GOL quickly became the second largest company in the aviation sector in Brazil. Moreover, GOL Airlines knew only too well the potential consequences of a small company and as far as it could get in terms of a market share.

Finally, Game Theory analyzes have shown that the company imposed prices that meant GVT had a permanence over WEBJET. This was proven fact by fact that WEBJET was to enter, so soon after starting its operations, with a performance by the Secretariat of Economic Law (ELS) against GVT, accusing it of having downloaded its prices, with a goal of harming WEBJET.

It is to be recommended that further research be conducted for the inbound and outbound processes of those companies with similar characteristics to WEBJET, including even those companies belonging to other sector oligopolists. Such research can contribute to the greater understanding of oligopolistic structures.

\section{References}

AGUIRREGABIRIA, V.; CHUN-YU, H. A Dynamic Game of Airline Network Competition: Huband-Spoke Networks and Entry Deterrence. International Journal of Industrial Organization, v. 28, p. 377-382, 2010.

ANAC. Agência Nacional da Aviação Civil. Anuários Estatísticos. 2008. Disponível em: <http://www2.anac.gov.br/imprensa/anuario2008.asp>. Acesso em: 03 jul. 2015.

AVIAÇÃO BRASIL. (2005). WebJet comemora resultados conquistados em duas semanas de operações. Disponível

em:

<http://www.aviacaobrasil.com.br/wp/noticias/noticias_online/WebJet_comemora_resultad os_conquistados_em_duas_semanas_de_operacoes>. Acesso em: 03 jul. 2014.

AZUL. AZUL cita negócio com TRIP como fator de risco. Disponível em: <http://rotadaaviacaonobrasil.blogspot.com.br/2013/05/azul-cita-negocio-com-trip-comofator-de-risco.htl>. Acesso em: 03 jul. 2015.

BAIN, J. S. Barriers to New Competition. Cambridge: Harvard University Press, 1956.

BERRY, S. Estimation of a Model of Entry in the Airline Industry. Econometrica, v.60, p.89-917, 1992.

BIELSCHOWSKI, P.; CUSTÓDIO, M. C. A evolução do setor de transporte aéreo brasileiro. Revista Eletrônica Novo Enfoque, v.13, p.72-93, 2011.

BRASIL. Nota Técnica no 29/2004/COGDC-DF/SEAE/MF - Versão Pública. Brasília: Secretaria de Acompanhamento Econômico (SEAE), 2004.

CRAVO, B. M. A alocação de slots e a concorrência no setor de transporte aéreo. Journal of Transport Literature, v. 8, n. 1, p. 159-177, 2014.

BRESNAHAN, T. F.; REISS, P. C. Entry in Monopoly Markets. Review of Economic Studies, v. 57, n. 4, p.531-53, 1990.

DAC. Departamento de Aviação Civil. Anuário de Dados Estatísticos 2005. Rio de Janeiro, 2005. 
CILIBERTO, F. Sequential Entry and Strategic Deterrence in the Airline Industry. Disponível em:

<http://www.fep.up.pt/conferences/earie2005/cd_rom/Session\%20III/III.I/Ciliberto_Entry. pdf $>$. Acesso em: 04 jun. 2015.

CHURCH, J. R., WAARE, R. Industrial Organization: A Strategic Approach. New York: McGrawHill, 2000.

FAGUNDES, J.; PONDÉ, J. L. Barreiras Entrada e Defesa da Concorrência: Notas Introdutórias. 2006. Disponível em: <http://www.ie.ufrj.br/grc/pdfs/barreiras_a_entrada_e_defesa_da_concorrencia.pdf>. Acesso em: 14 ago. 2015.

FERREIRA, N. S. Discussão das abordagens teóricas na investigação de práticas de concorrência predatória no transporte aéreo. Journal of Transport Literature, v.1, n.2, p.47-69, 2007.

FOLHA DE SÃO PAULO. Crise e disputa tarifária adiam entrada de novas empresas no setor aéreo. 2006. Disponível em: <http:/.www.folha.uol.com.br/fsp/dinheiro/ult91u102860>. Acesso em: 26 ago. 2015.

FOLHA DE SÃO PAULO. Entrada da Webjet detona disputa entre Varig, Gol e TAM. 2005. Disponível em: <http://.www.folha.uol.com.br/fsp/dinheiro/ult91u198131.shtml>. Acesso em: 26 nov. 2015.

GOOLSBEE, A., SYVERSON, C. How Do Incumbents Respond to the Threat of Entry? Evidence from the Major Airlines. Quarterly Journal of Economics, v.123, n.49, p. 1611-1633, 2008.

GEDGE, C.; ROBERTS, J. W.; SWEETINGZ, A. An Empirical Model of Dynamic Limit pricing: The Airline Industry. $2013 . \quad$ Disponível em: <http://public.econ.duke.edu/ atsweet/SWEETING_limitpricing.pdf, 2012>. Acesso em: 15 ago. 2015.

GOETZ, C. F.; SHAPIRO, A. H. Strategic alliance as a response to the threat of entry: Evidence from airline code sharing. International Journal of Industrial Organization, v.30, n.6, p.735$747,2012$.

HELMS, H. A aviação comercial e a quebra da Varig. Aviation in Focus (Porto Alegre), v.1, n. 1, p. $36-47,2010$.

HU, R.; XIA, H-S.; JIANG, Y. Complex Dynamics for Airlines' Price Competition with Differentiation Strategy. Journal of Transportation Systems Engineering and Information Technology, v. 13, n.1, p. 11-21, 2013.

KWOKA, J.; SHUMILKINA, E. The price effect of eliminating potential competition: Evidence from an airline merger. Journal of Industrial Economics, v. 58, n.4, p.767-793, 2010.

MCAFEE, R. P.; HUGO, M.; WILLIAMS, M. What is a barrier to entry? American Economic Review, v. 94, n.2, p. 461-465, 2004.

MEGHAN, B. Firm financial condition and airline price war. RAND Journal of Economic, v.33, n.2, p.298-318, 2002.

MELO FILHO, C. R.; SALGADO, L. H.; CESAR SATO, R.; OLIVEIRA, A. V. M. (2014). Modeling the effects of wage premiums on airline competition under asymmetric economies of density: A case study from Brazil. Journal of Air Transport Management, 36, 59-68. 
MIOTTO, G. R.; SOUZA, M. A.; DIEHL, C. A. (2008). Reflexos das Mudanças na Concorrência do Setor de Aviação Comercial Brasileiro: Um Estudo no Âmbito da Desregulamentação Governamental e da Entrada da Companhia Gol. ABCustos Associação Brasileira de Custos, v.3, n. 2, p.94-116, 2008.

OLIVEIRA, A. V. M. (2009). Estudos dos determinantes dos preços das companhias aéreas no mercado doméstico. Estudos regulatórios, ANAC, v.2, p.1-57, 2009.

OLIVEIRA, D. S.; RONZANI, G. M.; BANDEIRA, M. G., LOPES, L. S., \& OLIVEIRA, A. V. M. Estudo da Precificação de Companhias Aéreas em Rotas Domésticas de Longo Percurso. Engevista (UFF), v.8, n.1, p.4-15, 2006.

NOBRE, L. S. Modelo de entrada em mercados concentrados aplicado ao setor aéreo brasileiro. 2012. 33 f. Dissertação (Mestrado) - Programa de Pós-Graduação em Economia, CAEN, Universidade Federal do Ceará, Fortaleza-CE.

o TEMPO. Crise adia entrada de novas aéreas. 2006. Disponível em: <http://www.otempo.com.br/capa/economia/crise-adia-entrada-de-novas-a\%C3\%A9reas1.319598>. Acesso em: 07 mar. 2014.

PEARSONA, J.; O'CONNELLB, J. F.; PITTIFIELDA, D.; RYLEYC, T. The strategic capability of Asian network airlines to compete with low-cost carriers. Journal of Air Transport Management, v.47, p.1-10, 2015.

PEREIRA, B. A.; CAETANO, M. A conceptual business model framework applied to air transport. Journal of Air Transport Management, v. 44-45, p.70-76, 2015.

PACHECO, R. R.; BRAGAB, M. E.; FERNANDES, E. Spatial concentration and connectivity of international passenger traffic at Brazilian airports. Journal of Air Transport Management, v. 46, p.49-55, 2015.

PINTO, G. M. A. Competition and Predation in the Airline Industry. Disponível em: <http://works.bepress.com/gustavo_pinto/1>. Acesso em: 07 mar. 2014.

SENG POH, L.; MOHD, G. M. Competitive Pricing Strategies of Low Cost Airlines in the Perspective of Game theory. 2011. International Conference on Sociality and Economics Development IPEDR. Disponível em: <http://www.ipedr.com/vol10/92-S10055.pdf>. Acesso em: 22 mar. 2014.

ROBENALT, J. L. Predatory Pricing in the Low-Fare Airline Market: Targeted, Discriminatory, and Achieved with Impunity. Ohio State Law Journal, v.68, p.641-677, 2007.

SAMPAIO, B.; MELO, A. S. Análise da eficiência de Companhias Aéreas Brasileiras. Análise Econômica, Porto Alegre, v.26, n.50, p.223-244, 2008.

SEAE. Secretaria de Acompanhamento Econômico. 2002. Portaria no 70. de 12 de dezembro de 2002.

SEAE. Secretaria de Acompanhamento Econômico Coordenação Geral de Defesa da Concorrência - DF. 2004. Nota Técnica n.o 29/2004/COGDC-DF/SEAE/MF - Versão Pública. Disponível em: <http://www.seae.fazenda.gov.br/central_documentos/notas_imprensa/20031/ntcodeshareversaopublica-1/>. Acesso em: 12 mar. 2014.

SENA, A. M. C. O Duopólio das Empresas Aéreas Brasileiras TAM e GOL: uma Aplicação da Teoria dos Jogos à Competição Oligopolista Estratégica. RAC - Eletrônica, v.2, n.3, p.486-508, 2008. 
SILVEIRA, J. M.; OLIVEIRA, A. V. M. An empirical game-theoretical approach to model a price war in the Brazilian airline industry. Journal of Transport Literature, v.2, n.1, 7-20, 2008.

SOUZA, C. A. Senso de oportunidade da empresa Gol Linhas Aéreas no Mercado de aviação civil do Brasil. 33 f. 2006. Monografia (Graduação) - Curso de Graduação em Economia, UFSC, Universidade Federal de Santa Catarina, Florianópolis-SC.

TADEU, H. F.; SILVA, J. T. M. Brazilian Airline Competitive Market: Is There a Conceptual Framework Structure? Business Management Dynamics, v.1, n. 4, p. 09-19, 2011.

TOIVANEN, O.; WATERSON, M. Empirical Research on Discrete Choice Game Theory Models of Entry: An Illustration. European Economic Review, v. 44, n. 98. p. 5-92, 2000.

TUROllA, F. A.; LIMA, M. F. F.; OHIRA, T. H. Políticas públicas para a melhoria da competitividade da aviação regional brasileira. Journal of Transport Literature, v.5, n.4, 188231, 2011.

TUROLLA, F. A.; LOVADINE, D.; OLIVEIRA, A. V. M. Competição, colusão e antitruste: estimação da conduta competitiva de companhias aéreas. Rev. Bras. Econ. [online], v. 60, n. 4, p. 425-459, 2006

UEDA, T. V. A. Fusões no transporte aéreo: estudos e tendências. Journal of Transport Literature, v.6, n.4, p.215-227, 2012.

VALENT, V. D.; DORNELLES, G. S.; VALENT, J. Z. A inserção da Azul Linhas Aéreas no mercado brasileiro: o estudo descritivo de uma estratégia inovadora. Revista de Administração e Inovação, v.11, n. 3, p.125-149, 2014.

Received: 11/06/2016

Approved: 01/29/2017 